\title{
Journal of the Royal Asiatic Society
}

http://journals.cambridge.org/JRA

Additional services for Journal of the Royal Asiatic Society:

Email alerts: $\underline{\text { Click here }}$

Subscriptions: $\underline{\text { Click here }}$

Commercial reprints: $\underline{\text { Click here }}$

Terms of use : $\underline{\text { Click here }}$

\section{Reviews. Letter to the Disciple by Candragomin}

\section{H. Wenzel}

Journal of the Royal Asiatic Society / Volume 21 / Issue 04 / October 1889, pp 1133 - 1137

DOI: 10.1017/S0035869X00166018, Published online: 15 March 2011

Link to this article: http://journals.cambridge.org/ abstract S0035869X00166018

How to cite this article:

H. Wenzel (1889). V. Reviews. Letter to the Disciple by Candragomin. Journal of the Royal Asiatic Society, 21, pp 1133-1137 doi:10.1017/S0035869X00166018

Request Permissions : $\underline{\text { Click here }}$ 
upper cartouche is the following inscription in Phoenician letters: L-SH-L-M; in the lower is another in Phoenician letters: Y-R-M-Y-H-U. The two together read leshalom Yirmeyah" 'to the prosperity of Jeremiah.' The forms of the letters belong to the Phoenician, or rather the Israelitish, alphabet of the seventh century B.c. It is, therefore, possible that the seal may have been discovered on the site of Tel Defeneh or Tahpanhes, where a native was allowed by the authorities of the Bulaq Museum to excavate last year; and if so we may see in it an actual relic of the great Hebrew prophet. A copy of the seal is about to be published by M. Clermont-Ganneau.

\section{Reviews.}

\section{Letter to the Disciple by Candragomin.}

In the fourth volume of the 'Memoirs of the Oriental Section of the Imperial Russian Archeological Society, a journal in which many valuable contributions to Oriental literature in different branches have already appeared, Prof. Minayeff now gives us an edition of a Sanskrit poem ascribed to Candragomin, who is said to have sent it to a Prince Ratnakirti, and to have persuaded him thereby to forsake the world. This is the account given by Täranatha, and found also in Vairocanarakshita's commentary on the letter. (The Tibetan translation of this commentary is found in the same volume of the Sütra division of the Tanjur as that containing the letter itself, viz. vol. 94.)

Prof. Minayeff had published before, in the second volume of the same Journal, two short hymns, one to Avalokiteçvara (with some new remarks on that personality), and one to Buddha. But the present contribution outweighs them far in interest, as Candragomin is a celebrated name in Buddhist literature, and the author of many works, amongst which the Candra-vyākarana occupies a very high rank in the estimate of later, and even Brahmanical, authors. Dharmakīrti, according to Tāranātha, glories in being able to write. 
in the style of Candragomin. The same Tāranātha gives us the further data :

1) That Candragomin heard Sthiramati, who is mentioned by Hiouen Thsang as dead, and one of whose works was translated into Chinese under the Northern Liāng dynasty A.D. 397-439 (Bunyiu Nanjio, Catal. p. 273);

2) That he wrote as a comment on Pạnini the Candravyākarana with supplements, which work is made use of in the Käçika of Jayāditya, who, according to Itsing, died in the middle of the seventh century (Kielhorn in Ind. Ant. 1886; Max Müller, India, p. 346);

3) That he was an antagonist of Candrakirti (in the commentary, mentioned above, of our letter, Ratnakirti, the addressee, is called a pupil of Candrakirti), with whom he quarrelled for seven years;

4) And finally, as mentioned above, that he lived before Dharmakirti, one of whose works is quoted by Subandhu, who again is mentioned by Bāna, a contemporary of Hiouen Thsang (Vāsavadattā, ed. Hall, p. 23j, preface, p. 10, and Max Müller, India, p. 308).

In a passage of Itsing, translated by Mr. Ryauon Fujishima in the Journal Asiatique, Nov.-Dec. 1888, but of which Prof. Vassilieff gives a slightly different, and apparently more trustworthy, version, some of the principal teachers are grouped in three classes: the old, the mediæval, and those nearest the present time. Sthiramati is placed in the last of these classes, but Candragomin is not mentioned in them at all. On these data Prof. Minayeff comes to the probable conclusion that Candragomin lived in the fourth or the beginning of the fifth century A.D.

There is another passage from Isting which Prof. Minayeff adduces as referring to Candragomin: "In eastern India there lives a well known holy man called Ming Guan, ${ }^{1}$ who was still alive when I was there. Some people asked him 'What causes greater damage, a poisonous drug or a poisonous spectacle?' He answered, 'There is a wide

1 As the present writer does not know Chinese, he can only transcribe the Russian characters. 
difference between the two, a poisonous drug harms only if you eat it, but if you only think of a poisonous spectacle you burn." (Here again the French translation deviates in a rather unaccountable way; the name of the man is given as $Y i$ Youë̈!). The answer is the contents of v. 74 of the Sanskrit manuscripts (one Prof. Minayeff's own, the other the Cambridge Manuscript, Bendall Cat., p. 31). But as this verse is not found in the Tibetan translation, and is of different metre from the surrounding verses (indeed the only common çloka in the whole poem), and as these Sanskrit manuscripts are, in other respects, very defective, the reviewer would prefer to see in the above story only a further proof that this verse is interpolated. It occurs, as already pointed out by Prof. Minayeff, in vol. ii. p. 276 of the same Journal, in the Subhāshitâvali (in Böhtlingk's Ind. Spr. 6225), and is probably a verse of unknown authorship current among Buddhists and other saints. What is the meaning of Ming Guan, and would Itsing not know a man of Candragomin's importance and his works?

This letter, then, is a poem of 115 resp. $114 \mathrm{vv}$. (the Tibetan translation has two more, one between v. 63 and v. 64 of the Sanskrit text, and one between v. 69 and v. 70), in different metres, whose chief subject is the misery of being, written in a florid style with a superfluity of epithets.

After an introduction of eighteen verses in praise of 'the three Jewels" the author goes on (v. 19): "Entering this illsmelling abode of birth, which is filled with heaps of impurity, is very narrow, and is pervaded by dense darkness, as into some hell, he has to endure great misery with crushed limbs."

Then follow verses on the misery of age, which, enfeebling all man's faculties, sets its foot on his head against his will and drives him on as a cornac the elephant by the hook of its wrinkles (v. 25). Then he will repent of what he did and did not do (v. 30), for then the messengers of Yama will take him by the hair and carry him before the judge (v. 33-34).

1 According to the Cha-gati-dipani (a Pāli work translated from Sanskrit, of 
Next follows in our poem the description of tortures of the Pretas (vv. 35-40); they see water from afar, but at their approach it turns into mud, the pleasing shades of the forest turn into burning flames, the sea into a waste; the clouds rain down for them not drops of water but darts and stones; even the wind burns them, even the fire freezes them; their mouth is like the eye of a needle, their belly many yojanas wide; if they try to drink the ocean dries up ${ }^{1}$ Verses 41-60 give the picture of the pains of hell; not the eight great hells, but only the four vestibules of hell (nirayass' ussada) being described here; these are (1) the pit of excrements; (2) the burning coals; (3) the forest with swordleaved trees; ( 4 ) the river Vaitarani (comp. the Fr. Ep. vv. 71,72; and especially Pañea Gati Dippana, ed. Feer, J.P.T.S. 1884, v. 22 sq.). Prof. Minayeff quotes the Nemijatalka, of which he has published a Russian translation, and the Mahavastu, vol. i. p. 12. A Güthaniraya is mentioned in the commentary to the Dhammapada, ed. Fausböll, p. 408, and the same pains of hell are described in the Ashțākshaṇa-kathā, ${ }^{2}$ ascribed to Nāgārjuna (the Tibetan translation of which is in the same volume of the Tanjur). The difficulty of obtaining birth as a man and the 'unfavourable moments' are touched upon in $\nabla v .61-63$, the transitoriness of life in v. 65 sq., the vanity of earthly pleasures and pursuits in $\mathrm{vv} .67-71$; the sense-objects (vishaya) are described as worse than poison (visha) in vv. $72-76$. But also the gods must die, and Çakra must undergo new births (vv. 77-86) ; here again the chief points are the same as in the Fr. Ep. v. 98 sq., also 70 sq. ; the Mandākinī and the elastic ground of Mount Meru recur here (v. 79). Then follows the admonition in v. 87 : "As far as you form the thought (samjña) that this whole world is happiness, the worse the darkness of ignorance will grow, but as far as you form the thought of pain in

which Prof. Minayeff brought a manuscript from Mandalay) the Yamaloka-niraya are situated above the eight principal hells, on the four corners of Samjiva, the uppermost of these eight.

'Comp. on this point also the 'Friendly Epistle' (perhaps 'Epistle to a Friend' would be more accurate) of Nāgārjuna, 'Journal of the Pāli T.S.' 1886, v. 91 sq.

2 'Description of the eight unfavourable moments,' see Fr. Ep. v. 61. 
regard to this whole world, so far the darkness of ignorance will grow thin."

88. "As far as meditation on pleasing objects is indulged in, so much the more will spread the flame of lust; as far as meditation on unpleasing objects is exercised, so much will the flame of lust decrease." 1

I have translated this according to the Tibetan; in the Sunskrit, as printed here, two padas have been lost $(87 c$, $8 \& d)$, and the rest transposed.

To exert one's self in the interest of others is the true way of salvation (v. 90 sq.) ; for those that are overcome by thirst in the desert be thou a tree, a cloud, a pond (v. 109 sq.). Finally the author closes with the wish that all the world may obtain omniscience (v. $112 \mathrm{sq}$.).

Professor Minayeff has rendered a fresh service to the history of the variations of early Buddhist belief by the publication of this little poem.

H. WENzEL.

1 The last words in the original are not quite clear to me (shin tu rtse zhil hgyur), but must mean something to this effect. 